\title{
Sanitary aspects and technological challenges of whole milk microfiltration at low temperatures
}

\author{
Rafael Fagnani(1), Marisa Marroni Mexia(1), Ana Amélia Nunes Puppio(1) and Ana Paula Pavão Battaglini(2)
}

\begin{abstract}
(1)Universidade Norte do Paraná, Rua Marselha, no 591, Jardim Piza, CEP 86041-140 Londrina, PR, Brazil. E-mail: rafaelfagnani@hotmail.com, isamexia@hotmail.com, anaampuppio@hotmail.com (2)Universidade Estadual de Londrina, Departamento de Medicina Veterinária Preventiva, Campus Universitário, Rodovia Celso Garcia Cid, PR 445, Km 380, Caixa Postal 10011, CEP 86057-970 Londrina, PR, Brazil. E-mail: apaulabattaglini@hotmail.com
\end{abstract}

\begin{abstract}
The objective of this work was to evaluate the effects of whole milk microfiltration at low temperatures on bacterial counts and on its shelf life. The microfiltration process was evaluated at two temperatures ( 30 and $50^{\circ} \mathrm{C}$ ) and compared with the slow pasteurization process. Both slow pasteurization and microfiltration reduced the initial counts of aerobic mesophilic and psychrotrophic bacteria, as well as total coliforms in whole milk. Microfiltration at $50^{\circ} \mathrm{C}$ was as effective as the pasteurization process, since it reduced the initial count of aerobic mesophilic bacteria in $4.4 \log$ cycles; increased the product's shelf life, which reached 30 days without exceeding 1,000 $\mathrm{CFU} \mathrm{mL} \mathrm{mL}^{-1}$; and eliminated coliform counts at the temperatures of 35 and $45^{\circ} \mathrm{C}$, established by the Brazilian legislation. Microfiltration at $30^{\circ} \mathrm{C}$ reduced the aerobic mesophilic bacteria counts by $2.2 \log$ cycles; however, Escherichia coli was found in the product, which exhibited a shelf life of less than five days. Therefore, microfiltration at $30^{\circ} \mathrm{C}$ can be associated with thermal treatments, but, when applied alone, it shows unsatisfactory results.
\end{abstract}

Index terms: Escherichia coli, membrane, microbiological quality, pasteurization, shelf life.

\section{Aspectos sanitários e desafios tecnológicos da microfiltração de leite integral a baixas temperaturas}

\begin{abstract}
Resumo - O objetivo deste trabalho foi avaliar os efeitos da microfiltração do leite integral a baixas temperaturas, nas contagens bacterianas e na sua vida de prateleira. O processo de microfiltração foi avaliado a duas temperaturas $\left(30 \mathrm{e} 50^{\circ} \mathrm{C}\right)$ e comparado à pasteurização lenta. Tanto a pasteurização quanto a microfiltração reduziram as contagens iniciais de bactérias aeróbias mesófilas e psicrotróficas, bem como a de coliformes totais no leite integral. A microfiltração a $50^{\circ} \mathrm{C}$ foi tão efetiva quanto o processo de pasteurização, tendo reduzido as contagens iniciais de bactérias aeróbias mesófilas em 4,4 ciclos logarítimicos; aumentado a durabilidade do produto, que atingiu 30 dias sem exceder $1.000 \mathrm{UFC} \mathrm{mL}^{-1}$; e eliminado coliformes nas temperaturas de 35 e $45^{\circ} \mathrm{C}$, estabelecidas pela legislação brasileira. A microfiltração a $30^{\circ} \mathrm{C}$ reduziu as contagens iniciais de bactérias aeróbias mesófilas em 2,2 ciclos logarítimicos; entretanto, Escherichia coli foi detectada no produto, que apresentou vida útil inferior a cinco dias. Portanto, a microfiltração a $30^{\circ} \mathrm{C}$ pode ser associada a tratamentos térmicos, mas, quando aplicada isoladamente, apresenta resultados insatisfatórios.
\end{abstract}

Termos para indexação: Escherichia coli, membrana, qualidade microbiológica, pasteurização, vida de prateleira.

\section{Introduction}

Membrane processes have been major tools in food processing for more than 25 years, making the food industry responsible for a significant part of the turnover of the membrane manufacturing industry worldwide (Fernández García et al., 2013). Membrane filtration is a pressure-driven separation process that uses semipermeable polymeric or ceramic materials, in which part of the feedstock is rejected or retained, according to the pore size distribution of the membrane. Microfiltration uses pore size diameters of $0.2-2.0 \mu \mathrm{m}$ and operation pressures of $0.05-0.2 \mathrm{MPa}$, allowing the retention of milk particles, such as somatic cells, fat globules, bacteria, and casein micelles (Walstra et al., 2005; Coimbra \& Teixeira, 2010).

To extend the shelf life of milk, while maintaining its sensorial and nutritional properties, is an evolution of the dairy industry that seems far from the reality of countries in development. However, gathering the 
main variables that affect membrane processes and researching them in these countries can provide more realistic results.

The Southern Cone countries of Latin America have very particular characteristics regarding milk production and processing, but, overall, the microbiological quality of milk must still be improved. Due to large geographic extensions, for example, the microbiological count in this region is very irregular, oscillating between $1,400,000$ and 1,000 cells per $\mathrm{mL}$ (Battaglini et al., 2013; Bolaños et al., 2014; Fagnani et al., 2014).

The main strategies to produce milk with extended shelf life include: using good quality raw milk, i.e., with $<50,000$ colony forming units (CFU) per $\mathrm{mL}$; processing raw milk as soon as possible; minimizing pre-contamination; and deactivating thermolabile spores, especially the psychrotrophic ones (Barbano et al., 2006). In this regard, the quality of raw milk is one of the most important issues to extend the shelf life of milk using membrane filtration; however, questions still remain about its applicability in regions where milk quality could be defective.

Due to its technological limitations, microfiltration is usually applied to skim milk at temperatures between 50 and $55^{\circ} \mathrm{C}$. Lipid composition and low temperature conditions are limiting factors for the membrane technology, leading to a decrease in the membrane flow and to a greater probability of pore clogging.

Several studies have investigated microfiltration processes of whole milk at cold temperatures, ranging from 40 to $7^{\circ} \mathrm{C}$, with good permeation rates and significant reductions in microbial counts when compared with skim milk (Fritsch et al., 2005; Brito-de la Fuente et al., 2010). However, in these studies, the authors did not evaluate the presence of indicator bacteria in the permeate, which puts in doubt whether these isolated cases are enough to ensure the product's safety.

Surprisingly, there is no known work considering the sanitary aspects of whole milk microfiltration at low temperatures. Recently, Tan et al. (2014) published an investigation about membrane fouling in cold microfiltration of skim milk, but without an overview on the sanitary aspects.

The objective of this work was to evaluate the effects of whole milk microfiltration at low temperatures on bacterial counts and on its shelf life.

\section{Materials and Methods}

Fresh bulk milk (40 L) was obtained from one experimental farm with six healthy cows (four Holstein plus two Jersey), which had been milked using a mechanical open-circuit system. The dairy cows were selected because they complied with well-established criteria regarding the production of quality raw milk, i.e., good milking and herd management practices, besides low somatic cell and total bacteria counts at the bulk tank.

All the raw milk samples were collected from the bulk tank at the end of milking. Each sample (40 L) was transported within $10 \mathrm{~min}$ to the pilot plant, in a clean and sanitized milk can, at room temperature. The microfiltration process was carried out following the schematic diagram shown in Figure 1, which included milk refrigeration at $4{ }^{\circ} \mathrm{C}$, for 24 hours, before all the subsequent processes.

The following independent treatments were evaluated: microfiltration at $30^{\circ} \mathrm{C}$; microfiltration at $50^{\circ} \mathrm{C}$; and low-temperature, long-time (LTLT) pasteurization. Each treatment was repeated five times.

The experiments were conducted in a pilot skid system (Tia Brasil, Araraquara, SP, Brazil), designed for batch or continuous pilot plant use. The system had a 50-L stainless steel feed tank and was equipped with a 1.4- $\mu \mathrm{m}$ GP multichannel ceramic (aluminum oxide) membrane with 19 channels, each with diameter of $4 \mathrm{~mm}$, filtration area of $0.24 \mathrm{~m}^{2}$, and length of $1.02 \mathrm{~m}$ Membralox P19-40 GL and GP5020 (Pall Corporation, Port Washington, NY, USA).

The microfiltration system was sanitized with $200 \mathrm{ppm}$ sodium hypochlorite solution at $20^{\circ} \mathrm{C}$, for $20 \mathrm{~min}$, prior to the experiments. After each sanitization, the solution was rinsed out with demineralized water until the $\mathrm{pH}$ of the retentate and permeate streams was equal to that of the demineralized water.

At the start of the whole milk filtration, the remaining water was flushed out with the milk until the undiluted milk and permeate could be recirculated to the feed tank. Then, the milk and the microfiltration system were preheated, recycling the whole raw milk, at $4^{\circ} \mathrm{C}$, through the membrane with the permeate valve closed for temperature adjusting. Circulating hot water was fed to the heat exchanger in order to control the temperature at 30 or $50^{\circ} \mathrm{C}$ in the microfiltration experiments. The permeate valve was opened when the desired temperature was reached.

Pesq. agropec. bras., Brasília, v.51, n.8, p.990-997, ago. 2016 DOI: 10.1590/S0100-204X2016000800011 
The filtration experiment was conducted with two independent treatments, using different temperatures as variable parameters. Treatment $\mathrm{A}$ was performed in a batch mode with: $20-\mathrm{L}$ feed; 500,400 , and $0 \mathrm{kPa}$, respectively, in the $\mathrm{P} 1, \mathrm{P} 2$, and $\mathrm{P} 3$ pressure gauges, and $450 \mathrm{kPa}$ transmembrane pressure; permeate flux rate of $100 \mathrm{~L} \mathrm{~h}^{-1} \mathrm{~m}^{-2}$; and temperature of $30^{\circ} \mathrm{C}$. The same parameters were repeated in treatment $\mathrm{B}$, but with a temperature of $50^{\circ} \mathrm{C}$.

Samples $(500 \mathrm{~mL})$ of permeate and retentate were removed from the end of their respective return pipes, placed into sterile bags, then stored at $4^{\circ} \mathrm{C}$ for analysis on the same day and also for shelf-life studies.

Raw whole milk at $4{ }^{\circ} \mathrm{C}$ was collected into sterile containers and pasteurized in a LTLT water bath system model 550 (Fisatom Equipamentos Científicos Ltda., São Paulo, SP, Brazil) at $60^{\circ} \mathrm{C}$ and a holding time of $30 \mathrm{~min}$. The effectiveness of pasteurization was tested using colorimetric strips (Laborclin - Produtos para Laboratório, Pinhais, PR, Brazil), which detects the presence of alkaline phosphatase with a sensitivity to $1 \%$ raw milk (Seixas et al., 2014). After pasteurization, the milk was collected into sterile glass tubes and stored at $4^{\circ} \mathrm{C}$ for analysis on the same day and also for shelf-life studies.

For those studies, five samples of each thermal treatment, i.e., microfiltration at $30^{\circ} \mathrm{C}$, microfiltration at $50^{\circ} \mathrm{C}$, and LTLT pasteurization, were stored at $4^{\circ} \mathrm{C}$ for 24 hours, $5,10,15$, and 30 days.

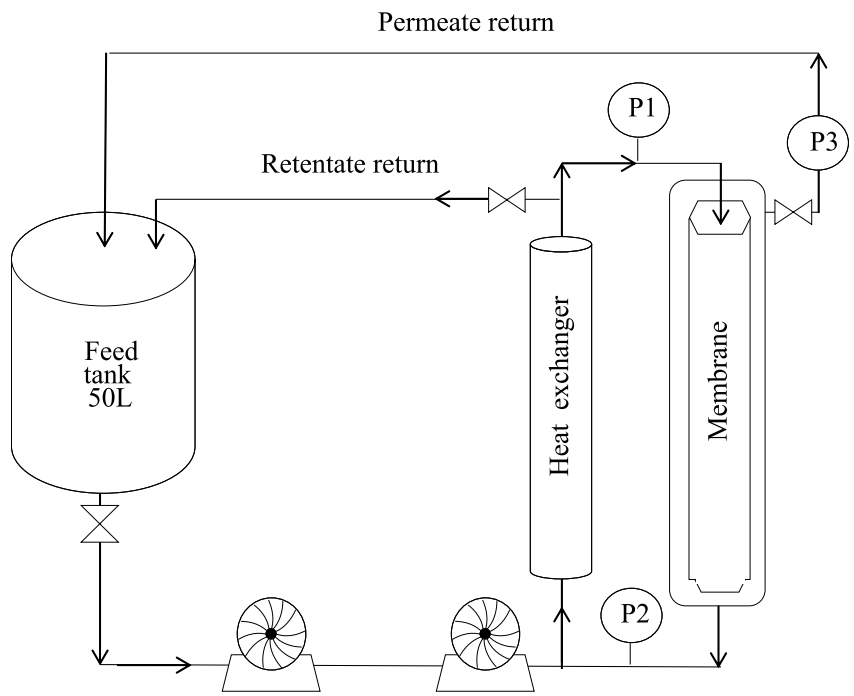

Figure 1. Diagram of the pilot-scale microfiltration, with the P1, P2, and P3 pressure gauges.
To evaluate the microbiological and chemical properties of the milk during shelf life, the following were obtained: aerobic mesophilic bacteria, psychrotrophic bacteria, total coliforms, and Escherichia coli counts; as well as fat, total protein, total solids, and lactose contents.

The shelf life of the pasteurized milk subjected to microfiltration was determined considering the maximum limits for aerobic mesophilic bacteria and coliform counts at 35 and $45^{\circ} \mathrm{C}$, which are the temperatures established by the Brazilian legislation for type A milk. This legislation is based on the United States Food and Drug Administration (FDA) and is also a reference for the Common Market of the Southern Cone (Mercosur) countries. It allows maximum counts of $1,000 \mathrm{CFU} \mathrm{mL}^{-1}(3.0 \mathrm{log})$, for aerobic mesophilic bacteria; below 1 most probable number (MPN) or CFU mL $\mathrm{m}^{-1}$, for coliforms at $35^{\circ} \mathrm{C}$; and absence of coliforms at $45^{\circ} \mathrm{C}$ (Brasil, 2011). These values show that the regulation of pasteurized type $\mathrm{A}$ milk in Brazil is more rigid than the existing legislation in the United States. The Pasteurized Milk Ordinance regulatory standards require pasteurized fluid milk to have less than 20,000 CFU mL $\mathrm{m}^{-1}$ (United States Public Health Service, 2011); in practice, this criterion may be applied one day after pasteurization.

The aerobic mesophilic bacteria were assessed using traditional plate count agar (PCA) media. One milliliter of each serially diluted sample was added to a Petri dish plate, followed by the addition of $20 \mathrm{~mL}$ of PCA medium, then was incubated at $37^{\circ} \mathrm{C}$ for 48 hours, in duplicate. The psychrotrophic microorganisms were determined by surface plating on PCA medium $(0.1 \mathrm{~mL}$ of each serially diluted sample) with a sterile Drigalski spatula, with incubation at $21^{\circ} \mathrm{C}$ for 25 hours, also in duplicate (Davidson et al., 2004).

Total coliforms and E. coli were evaluated by incubation of the sample in plates (3M Petrifilm EC) at $37^{\circ} \mathrm{C}$, for 24 and 48 hours, respectively. Petrifilm was used according to the manufacturer's instructions. The cover film of each dry medium culture plate was opened, and then $1 \mathrm{~mL}$ of decimal dilution was added to the bottom film. The cover films were subsequently covered and pressed with a spreader, in order to spread the sample uniformly.

The percentages of fat, total protein, lactose, and total solids were measured using the infrared methodology, method number 33.2.31, 972.26 (Horwitz, 2000). Samples $(100 \mathrm{~mL})$ of raw whole milk, microfiltered 
milk at $30^{\circ} \mathrm{C}$, microfiltered milk at $50^{\circ} \mathrm{C}$, and LTLT pasteurized milk were analyzed on the same day as the microfiltration processes and also during shelf-life evaluations.

Data were subjected to the Kolmogorov-Smirnov test to check normality and homoscedasticity. Since normal distribution was not observed, the numerical variables (aerobic mesophilic bacteria, psychrotrophic bacteria, and coliform counts) were categorized using an ordinal scale by logarithmic transformation.

The reduction in the microbial content of the milk was assessed before and after each thermal treatment with the Wilcoxon test, at $5 \%$ probability. The variables of each thermal treatment were also compared using the Mann-Whitney test, at $5 \%$ probability. The analyses were performed using the software Statistica, version 7.0 (Dell Statistica, Tulsa, OK, USA), and the experiments report the averages of five measurements.

\section{Results and Discussion}

LTLT pasteurization and microfiltration at 30 and $50^{\circ} \mathrm{C}$ reduced the initial counts of aerobic mesophilic and psychrotrophic bacteria and of total coliforms in raw milk (Table 1).

Microfiltration at $30^{\circ} \mathrm{C}$ reduced the aerobic mesophilic count by 2.2 log cycles, being less effective than pasteurization, which decreased the mesophilic bacteria count by $3.78 \log$ cycles. Similar behavior was observed for microfiltration at $50^{\circ} \mathrm{C}$. For the permeate, at $50^{\circ} \mathrm{C}$, reductions of $4.4 \log$ cycles were verified, which did not differ significantly from the decrease of 5.59 cycles observed with the pasteurization process.

Therefore, greater reductions in aerobic mesophilic bacteria counts were found in the microfiltration process at $50^{\circ} \mathrm{C}$, when compared with microfiltration at $30^{\circ} \mathrm{C}$. The average counts in the permeates at 30 and $50^{\circ} \mathrm{C}$ were 3.06 and $1.14 \log \mathrm{CFU} \mathrm{mL} \mathrm{mL}^{-1}$, respectively (Table 1). These logarithmic reductions in bacteria and spore counts help to lengthen the refrigerated shelf life of pasteurized milk. Schaffner et al. (2003) reported that reducing the average initial microbial contamination level by $0.5 \mathrm{log}$ can significantly reduce the fraction of milk samples that spoil after 14 days of refrigerated shelf life, when either mesophilic or psychotropic microbes are present.

Various studies have shown the effect of microfiltration on reducing microorganism and spore counts in milk. Hoffmann et al. (2006) used 1.4- $\mu \mathrm{m}$ ceramic membranes to reduce total bacteria count of raw skim milk by $99.85 \%$, with an average log reduction of 2.8. Elwell \& Barbano (2006) used the same type of membrane and found a $3.79 \mathrm{log}$ reduction in total bacteria in raw skim milk. The high effectiveness of this technique in reducing bacterial levels in milk was also confirmed in a study by Olesen \& Jensen (1989), which showed a significant reduction of 4.0 and 2.3-3.7 log, respectively, in total bacteria and spore count.

Regarding psychrotrophic bacteria, both microfiltration temperatures were effective in reducing microbial counts, with no significant differences in the permeates at 30 and $50^{\circ} \mathrm{C}$, when compared with LTLT pasteurization. However, a higher decrease was observed with microfiltration at $50^{\circ} \mathrm{C}$ than at $30^{\circ} \mathrm{C}$. In all experiments, the permeate at $50^{\circ} \mathrm{C}$ showed a psychrotrophic bacteria count lower than the limit of $10 \mathrm{CFU} \mathrm{mL} \mathrm{m}^{-1}$; whereas, at $30^{\circ} \mathrm{C}$, it had counts of up to $2.82 \times 10^{5} \mathrm{CFU} \mathrm{mL}^{-1}$.

For total coliforms, microfiltration at $30^{\circ} \mathrm{C}$ was less effective than both LTLT pasteurization and microfiltration at $50^{\circ} \mathrm{C}$, with bacterial counts of $17 \mathrm{CFU} \mathrm{mL}^{-1}$ in the permeate. Microfiltration at $50^{\circ} \mathrm{C}$ and pasteurization had similar coliform counts, lower than the limit value of $1 \mathrm{CFU} \mathrm{mL} \mathrm{m}^{-1}$ in all experiments (Table 1).

Table 1. Median and confidence interval at $95 \%$ of aerobic mesophilic bacteria (Am), psychrotrophic bacteria (Psy), total coliform (Tc), and Escherichia coli $(\mathrm{Ec})$ count of raw milk, permeate skim milk, and low-temperature, long-time (LTLT) pasteurized milk, grouped by microfiltration temperature ${ }^{(1)}$.

\begin{tabular}{lccc}
\hline $\begin{array}{l}\text { Micro- } \\
\text { organism }\end{array}$ & $\begin{array}{c}\text { Raw } \\
\text { milk }\end{array}$ & $\begin{array}{c}\text { Permeate skim } \\
\text { milk }\end{array}$ & $\begin{array}{c}\text { LTLT pasteurized } \\
\text { milk }\end{array}$ \\
\hline \multicolumn{5}{c}{ Microfiltration at $30^{\circ} \mathrm{C}$} \\
Am & --------------------- \\
Psy & $6.06 \mathrm{aA} ; 3.56 \mathrm{H} 7.54$ & $3.40 \mathrm{bA} ; 0.51 \mathrm{H} 5.40$ & $1.78 \mathrm{bA} ; 1.00 \mathrm{H} 2.54$ \\
Tc & $3.18 \mathrm{aA} ; 0.67 \mathrm{H} 5.51$ & $0.00 \mathrm{bA} ;-0.33 \mathrm{H} 1.08$ & $<-0.05 \mathrm{cA} ;^{(2)}$ \\
Ec & $-0.05 \mathrm{aA} ;-0.43 \mathrm{H} 1.37$ & $-0.05 \mathrm{abA} ;-0.06 \mathrm{H}-0.01$ & $<-0.05 \mathrm{bA} ;{ }^{(2)}$ \\
\hline \multicolumn{4}{c}{ Microfiltration at $50^{\circ} \mathrm{C}$} \\
Am & $5.54 \mathrm{aA} ; 5.19 \mathrm{H} 5.81$ & $1.14 \mathrm{bB} ; 0.72 \mathrm{H} 2.59$ & $-0.05 \mathrm{bA} ;-0.33 \mathrm{H} 1.26$ \\
Psy & $3.70 \mathrm{aA} ; 1.33 \mathrm{H} 4.27$ & $<-0.05 \mathrm{bB} ;{ }^{(2)}$ & $-0.02 \mathrm{bA} ;-0.0 \mathrm{H}-0.04$ \\
Tc & $3.35 \mathrm{aA} ; 2.18 \mathrm{H} 4.52$ & $<-0.05 \mathrm{bB} ;{ }^{(2)}$ & $<-0.05 \mathrm{bA} ;{ }^{(2)}$ \\
Ec & $-0.05 \mathrm{aA} ;-0.23 \mathrm{H} 0.47$ & $<-0.05 \mathrm{bA} ;{ }^{(2)}$ & $<-0.05 \mathrm{bA} ;{ }^{(2)}$ \\
\hline
\end{tabular}

(1)Medians followed by equal letters, lowercase in the rows and uppercase in the columns, do not differ, respectively, by the Wilcoxon test and by the Mann-Whitney test, at $5 \%$ probability. ${ }^{(2)}$ Not observed. 
As for E. coli presence, the permeate at $30^{\circ} \mathrm{C}$ showed $1 \mathrm{CFU} \mathrm{mL}{ }^{-1}$, while pasteurized milk and the permeate at $50^{\circ} \mathrm{C}$ had $E$. coli counts lower than the technical limit of $<1 \mathrm{CFU} \mathrm{mL} \mathrm{m}^{-1}$.

Despite its high efficiency in removing total bacteria and spores, microfiltration is not able to select types of microorganisms in the same way that milk pasteurization can. Therefore, this technique cannot guarantee $100 \%$ removal of pathogenic bacteria. This indicates that the use of microfiltration as a substitute for pasteurization should be viewed with caution, and that a strict sanitary control of the herd is indispensable in order to guarantee the safety of the final product.

Without associated heat treatment, the microfiltration process alone has not been recommended as a technology for processing dairy products. Considering the detection of coliforms at $30^{\circ} \mathrm{C}$ in the permeate, in the present study, the presence of Mycobacterium bovis cells cannot be ruled out, since both have similar thermal resistance (Walstra, 1999).

Schmidt et al. (2012) studied the incidence of different bacterial species at the end of the extended shelf life of milk stored at 4,8 , and $10^{\circ} \mathrm{C}$, when retailed in Germany, Austria, and Switzerland. Of the 125 packages analyzed, Bacillus cereus was detected in $4.8 \%$; Acinetobacter junii in $2.4 \%$; and Moraxella osloensis in $0.8 \%$. All the aforementioned microorganisms are classified in the risk II group of moderate individual risk and low community risk, according to German legislation. The general prevalence of B. cereus and of other bacteria of the risk II group was $12.1 \%$.

The mean fat content of the raw whole milk and of the pasteurized milk was $3.61 \pm 0.12 \%$. After microfiltration at 30 or $50^{\circ} \mathrm{C}$, the mean values were 0.01 and $0.00 \%$, with standard deviation lower than 0.01 (Table 2). It should be noted that microfiltration is usually not applied to whole milk because the fat globules are large (up to $15 \mu \mathrm{m}$ ), which can result in rapid fouling due to the deposition of a layer on the membrane surface. However, when applied to skim milk, it is possible to achieve a product that is $98 \%$ free of fat and with a finer texture and better taste (Glimenius et al., 1979; Goudédranche et al., 2000).

Several studies have investigated the cold microfiltration fouling of whole and skim milk, which has resulted in significant advances in relation to fouling mechanisms (Fritsch et al., 2005; Tan et al., 2014). Although the focus of the present study was the sanitary aspects and the shelf life of permeate in the microfiltration process, the following variables were related to fouling: volume concentration factor of 4.99; and decrease of $6875 \mathrm{~L} \mathrm{~h}^{-1} \mathrm{~m}^{-2}$ in the initial flux, caused by the increased viscosity of the retentate, of $580 \mathrm{~L} \mathrm{~h}^{-1} \mathrm{~m}^{-2}$.

The main advantage of the microfiltration process is its ability to have a minimal effect on the final product in terms of chemical, physical, and organoleptic properties, which does not occur in high-heat treatments (Fernández García et al., 2013). This was

Table 2. Median \pm standard deviation of fat, total proteins, lactose, and nonfat solids (NFS) of permeate skim milk, microfiltered milk at 30 and $50^{\circ} \mathrm{C}$, and long-term, long-time (LTLT) pasteurized milk, during shelf life ${ }^{(1)}$.

\begin{tabular}{|c|c|c|c|c|}
\hline $\begin{array}{l}\text { Shelf life } \\
\text { (days) }\end{array}$ & $\begin{array}{l}\text { Fat } \\
(\%)\end{array}$ & $\begin{array}{c}\text { Total proteins } \\
(\%)\end{array}$ & $\begin{array}{c}\text { Lactose } \\
(\%)\end{array}$ & $\begin{array}{l}\text { NFS } \\
(\%)\end{array}$ \\
\hline \multicolumn{5}{|c|}{ Microfiltration at $30^{\circ} \mathrm{C}$} \\
\hline 1 & $0.01 \mathrm{a} \pm 0.01$ & $3.69 \mathrm{a} \pm 0.61$ & $4.36 \mathrm{a} \pm 0.88$ & $9.18 \mathrm{a} \pm 0.94$ \\
\hline 5 & $0.01 \mathrm{a} \pm 0.00$ & $3.61 \mathrm{a} \pm 0.70$ & $4.34 \mathrm{a} \pm 0.82$ & $9.23 \mathrm{a} \pm 0.69$ \\
\hline $10-30$ & $-(2)$ & - & - & - \\
\hline \multicolumn{5}{|c|}{ Microfiltration at $50^{\circ} \mathrm{C}$} \\
\hline 1 & $0.00 \mathrm{a} \pm 0.00$ & $3.77 \mathrm{a} \pm 0.21$ & $4.45 \mathrm{a} \pm 0.98$ & $9.24 \mathrm{a} \pm 1.24$ \\
\hline 5 & $0.00 \mathrm{a} \pm 0.00$ & $3.71 \mathrm{a} \pm 0.66$ & $4.41 \mathrm{a} \pm 0.66$ & $9.17 \mathrm{a} \pm 1.14$ \\
\hline 10 & $0.00 \mathrm{a} \pm 0.01$ & $3.68 \mathrm{a} \pm 0.74$ & $4.41 \mathrm{a} \pm 0.67$ & $9.23 \mathrm{a} \pm 0.84$ \\
\hline 30 & $0.00 \mathrm{a} \pm 0.00$ & $3.62 \mathrm{a} \pm 0.87$ & $4.40 \mathrm{a} \pm 0.82$ & $9.21 \mathrm{a} \pm 1.21$ \\
\hline \multicolumn{5}{|c|}{ LTLT pasteurization } \\
\hline 1 & $3.62 \mathrm{~b} \pm 0.12$ & $3.73 \mathrm{a} \pm 0.41$ & $4.41 \mathrm{a} \pm 0.98$ & $9.21 \mathrm{a} \pm 1.41$ \\
\hline 5 & $3.60 \mathrm{~b} \pm 0.10$ & $3.66 \mathrm{a} \pm 0.68$ & $4.38 \mathrm{a} \pm 0.74$ & $9.30 \mathrm{a} \pm 0.99$ \\
\hline 10 & $3.61 \mathrm{~b} \pm 0.13$ & $3.66 \mathrm{a} \pm 0.69$ & $4.36 \mathrm{a} \pm 0.72$ & $9.22 \mathrm{a} \pm 0.89$ \\
\hline 30 & $3.62 b \pm 0.13$ & $3.62 \mathrm{a} \pm 0.72$ & $4.35 \mathrm{a} \pm 0.89$ & $9.21 \mathrm{a} \pm 1.10$ \\
\hline
\end{tabular}

${ }^{(1)}$ Medians followed by equal letters do not differ by Wilcoxon's test, at $5 \%$ probability. ${ }^{(2)}$ Not analyzed due to spoilage coagulation. 
also observed in the present study. The mean values in the raw whole milk for protein, lactose, and nonfat solids were $3.68,4.39$, and $9.22 \%$, respectively, and they remained unchanged after the microfiltration or pasteurization processes (Table 2).

The settings used in the present study - ceramic membrane of $1.4 \mu \mathrm{m}$, transmembrane pressure of up to $450 \mathrm{kPa}$, and a permeate flux rate of $100 \mathrm{~L} \mathrm{~h}^{-1} \mathrm{~m}^{2}$ - have been shown to minimize the compaction of the polarized layer that prevents the rejection of milk proteins. Furthermore, the ceramic membranes were hydrophilic, resulting in a lower level of protein adhesion to them (Baruah et al., 2006; Hoffman et al., 2006). Most of the studies that have used these parameters have reported that the total protein in the permeate was slightly decreased in $0.02 \%$, and that the ratio of protein fractions was unchanged (Lorenzen et al., 2011).

The average shelf life of LTLT pasteurized milk varied from 10 to 15 days after the heat treatment (Figure 2 A). Rysstad \& Kolstad (2006) found that the shelf life of pasteurized milk varied from 10 to 12 days, when stored at $6^{\circ} \mathrm{C}$, and from 3 to 4 days, at $10^{\circ} \mathrm{C}$.

The average shelf life of milk subjected to microfiltration at $30^{\circ} \mathrm{C}$ was lower than five days, under refrigerated storage at $4^{\circ} \mathrm{C}$ (Figure $2 \mathrm{~B}$ ). One day after processing, the samples had exceeded the maximum limit for aerobic mesophilic bacteria count. After five days at $4^{\circ} \mathrm{C}$, the samples exhibited average counts of $1.7 \log \mathrm{CFU} \mathrm{mL} \mathrm{m}^{-1}$ for coliforms evaluated at $35^{\circ} \mathrm{C}$, indicating poor milk quality. The psychrotrophic bacteria counts were also high, with initial counts of $3.3 \log \mathrm{CFU} \mathrm{mL}^{-1}$.

After five days of refrigerated storage, the average count of psychrotrophic bacteria in the milk subjected to microfiltration at $30^{\circ} \mathrm{C}$ reached $7.8 \log \mathrm{CFU} \mathrm{mL}-1$. In the European Economic Community, the current milk quality standards require that psychrotrophic microorganisms should not exceed $5 \times 10^{3} \mathrm{CFU} \mathrm{mL}^{-1}$.

This particular result showed the non-effectiveness of the milk microfiltration process at $30^{\circ} \mathrm{C}$ alone. Arcuri et al. (2008) concluded that Gram-negative bacteria are the main psychrotrophic microorganisms responsible for the deterioration of refrigerated milk, causing rancidity, a bitter taste, and lower yields in the manufacture of dairy products.

The shelf life of the milk microfiltered at $50^{\circ} \mathrm{C}$ reached 30 days without exceeding the microbiological limits prescribed by the law for aerobic mesophilic
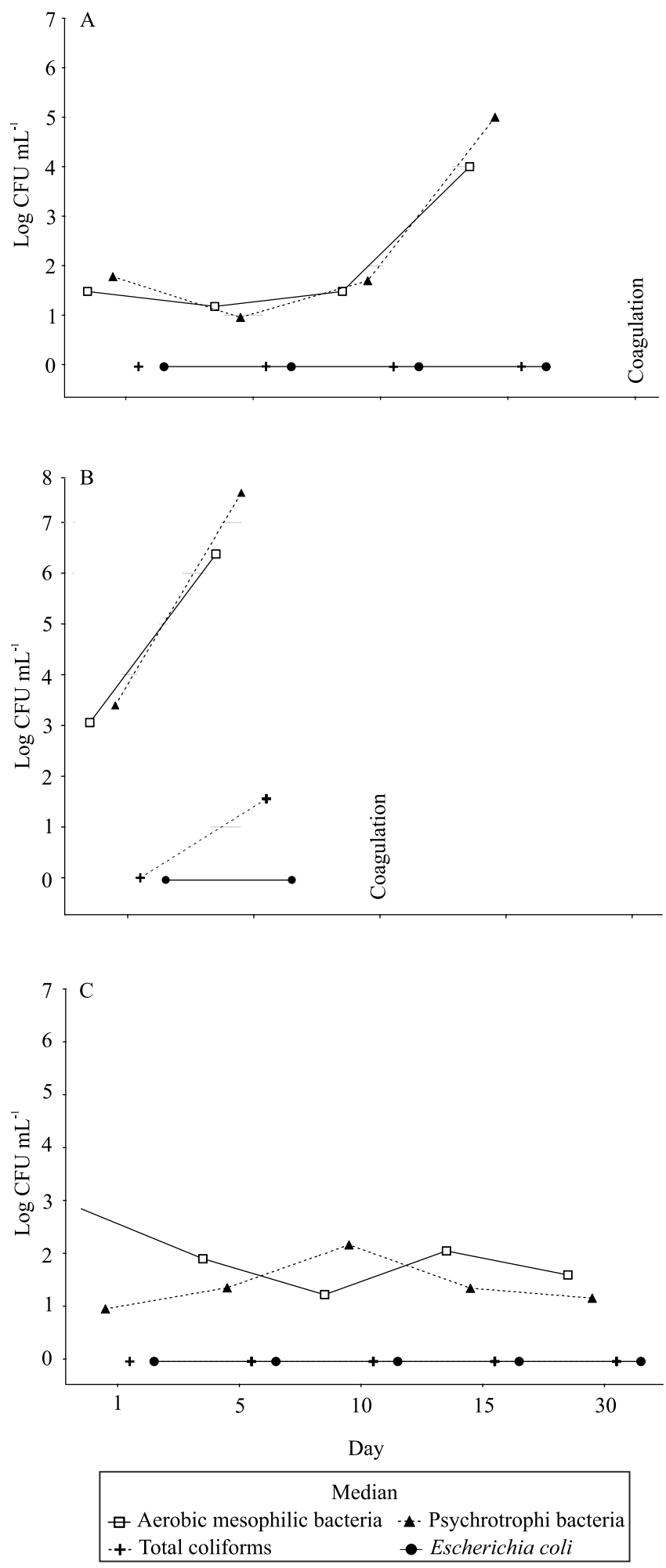

Figure 2. Oscillation count of aerobic mesophilic bacteria, psychrotrophic bacteria, total coliforms, and Escherichia coli of long-term, long-time (LTLT) pasteurized milk (A), and microfiltered milk at $30(\mathrm{~B})$ and $50^{\circ} \mathrm{C}(\mathrm{C})$ under storage at $4^{\circ} \mathrm{C}$, over shelf-life time. 
bacteria and coliform counts at 35 and $45^{\circ} \mathrm{C}$ (Figure 2C). When the microfiltration and pasteurization processes are combined, the shelf life of milk can reach up to 90 days. Antunes et al. (2014) studied microfiltered milk stored at $4^{\circ} \mathrm{C}$, for 35 days, and obtained aerobic mesophilic bacteria counts of $1.77 \log \mathrm{CFU} \mathrm{mL} \mathrm{m}^{-1}$, very close to those found in the present study, which were of $<2 \log \mathrm{CFU} \mathrm{mL}^{-1}$.

In the present study, the population of aerobic mesophilic bacteria in microfiltered milk at $50^{\circ} \mathrm{C}$ showed a tendency to decrease during storage at $4^{\circ} \mathrm{C}$. The aerobic mesophilic bacteria count presented maximum values of $2.85 \log \mathrm{CFU} \mathrm{mL} \mathrm{m}^{-1}$ on day 1 and minimum values of $1.2 \log \mathrm{CFU} \mathrm{mL} \mathrm{m}^{-1}$ on day 10 (Figure $2 \mathrm{C}$ ). Opposite behavior was observed for psychrotrophic bacteria count, with average value of $0.95 \log$ CFU mL $\mathrm{mL}^{-1}$ on day 1 and of $2.15 \log \mathrm{CFU} \mathrm{mL}-1$ on day 10.

This decreasing tendency toward mesophilic growth, accompanied by an increasing tendency toward psychrotrophic growth, which is related with the adaptation of microorganisms to cold (Souza et al, 2009), has also been reported by other authors. Most psychrotrophic bacteria have optimum growth at temperatures ranging from $20-30^{\circ} \mathrm{C}$, since they adapt to refrigeration temperatures. Temperatures around $4^{\circ} \mathrm{C}$ attract psychrotrophic microbiota, which multiply at refrigeration temperatures and produce heat-resistant enzymes, causing rancidity and lower yields in the manufacture of dairy products (Arcuri et al., 2008).

Interestingly, this microbiological pattern was not observed in the present study in relation to LTLT pasteurized milk. In this treatment, the multiplication of aerobic and psychrotrophic microorganisms followed a similar behavior, probably due to the selection of thermoduric microorganisms at the studied temperatures. In this case, there may have been more homogeneous species of microorganisms. Heat-resistant microorganisms are represented by Gram-positive nonspore-forming bacteria and by Gram-negative bacteria. These organisms gain significance if they are psychrophilic or psychrotrophic, multiplying at refrigeration temperatures (Lorenzen et al., 2011).

\section{Conclusions}

1. Microfiltration at $30^{\circ} \mathrm{C}$ is less effective in reducing microbial load and extending the shelf life of milk than microfiltration at $50^{\circ} \mathrm{C}$ and slow long-time, long-term (LTLT) pasteurization.

2. Microfiltration alone at $30^{\circ} \mathrm{C}$ is not suitable as a thermal processing technology for dairy products because total coliforms are found in the permeate.

3. Microfiltration at $50^{\circ} \mathrm{C}$ is equivalent to LTLT pasteurization, in terms of reducing microbial counts, and it can extend the product's shelf life by 15 to 20 days when compared with pasteurized milk.

4. Microfiltration at $50^{\circ} \mathrm{C}$ is a viable alternative to produce extended shelf life in milk without applying high temperatures, such as those used in pasteurization processes.

\section{Acknowledgments}

To Coordenação de aperfeiçoamento de Pessoal de Nível Superior (Capes) and to Fundação Nacional de Desenvolvimento do Ensino Superior Particular (Funadesp), for financial support; and to Centro Mesorregional de Excelência em Tecnologia do Leite do Norte Central of Universidade Estadual de Londrina (UEL), for donating raw milk.

\section{References}

ANTUNES, A.E.C; SILVA e ALVES, A.T.; GALLINA, D.A.; TRENTO, F.K.H.S.; ZACARCHENCO, P.B.; VAN DENDER, A.G.F.; MORENO, I.; ORMENESE, R.C.S.C.; SPADOTI, L.M. Development and shelf-life determination of pasteurized, microfiltered, lactose hydrolyzed skim milk. Journal of Dairy Science, v.97, p.5337-5344, 2014. DOI: 10.3168/jds.2014-8020.

ARCURI, E.F.; SILVA, P.D.L. da; BRITO, M.A.V.P.; BRITO, J.R.F.; LANGE, C.C.; MAGALHÃES, M.M. dos A. Contagem, isolamento e caracterização de bactérias psicrotróficas contaminantes de leite cru refrigerado. Ciência Rural, v.38 p.2250-2255, 2008. DOI: 10.1590/S0103-84782008000800025.

BARBANO, D.M.; MA, Y.; SANTOS, M.V. Influence of raw milk quality on fluid milk shelf life. Journal of Dairy Science, v.89, p.E15-E19, 2006. DOI: 10.3168/jds.S0022-0302(06)72360-8.

BARUAH, G.L.; NAYAK, A.; BELFORT, G. Scale-up from laboratory microfiltration to a ceramic pilot plant: design and performance. Journal of Membrane Science, v.274, p.56-63, 2006. DOI: 10.1016/j.memsci.2005.07.046.

BATTAGLINI, A.P.P.; BELOTI, V.; FAGNANI, R.; TAMANINI, R.; DUNGA, K. da S. Caracterização físico-química e microbiológica do leite bovino instável não ácido em função das estações do ano. Revista Brasileira de Medicina Veterinária, v.35, p.26-32, 2013.

BOLAÑOS, C.A.D.; PANTOJA, J.C.F.; ALVES, A.C.; RISSETI, R.M.; LISTONI, F.J.P.; RIBEIRO, M.G. Qualidade do leite de 
vacas criadas no sistema silvipastoril no Vale do Cauca, Colômbia. Pesquisa Veterinária Brasileira, v.34, p.134-140, 2014. DOI: 10.1590/S0100-736X2014000200007.

BRASIL. Ministério da Agricultura, Pecuária e Abastecimento. Instrução Normativa, $\mathrm{n}^{\circ}$ 62, de 29 de dezembro de 2011. Diário Oficial [da] União, Brasília, DF, 30 dez. 2011. Seção 1, p.6-11.

BRITO-DE LA FUENTE, E.; TORRESTIANA-SÁNCHEZ, B.; MARTÍNEZ-GONZÁLEZ, E.; MAINOU-SIERRA, J.M. Microfiltration of whole milk with silicon microsieves: effect of process variables. Chemical Engineering Research and Design, v.88, p.653-660, 2010. DOI: 10.1016/j.cherd.2009.09.014.

COIMBRA, J.S. dos R.; TEIXEIRA, J.A. (Ed.). Engineering aspects of milk and dairy products. Boca Raton: Taylor and Francis Group, 2010. 673p.

DAVIDSON, P.M.; ROTH, L.A.; GAMBREL-LENARZ, S.A.; BRUHN, J. Coliform and other indicator bacteria. In: WEHR, H.M.; FRANK, J.F. (Ed.). Standard methods for the examination of dairy products. $17^{\text {th }}$ ed. Washington: American Public Health Association, 2004. DOI: 10.2105/9780875530024ch07.

ELWELL, M.W.; BARBANO, D.M. Use of microfiltration to improve fluid milk quality. Journal of Dairy Science, v.89, p.E20-E30, 2006. Supplement. DOI: 10.3168/jds. S0022-0302(06)72361-X.

FAGNANI, R.; BATTAGLINI, A.P.P.; BELOTI, V.; SCHUCK, J.; SEIXAS, F.N.; CARRARO, P.E. Parâmetros físico-químicos e microbiológicos do leite em função da sazonalidade. Revista do Instituto de Laticínios Cândido Tostes, v.69 p.173-180, 2014. DOI: 10.14295/2238-6416.v69i3.311.

FERNÁNDEZ GARCÍA, L.; ÁLVAREZ BLANCO, S.; RIERA RODRÍGUEZ, F.A. Microfiltration applied to dairy streams: removal of bacteria. Journal of the Science of Food and Agriculture, v.93, p.187-196, 2013. DOI: 10.1002/jsfa.5935.

FRITSCH, J. de A.; BELICIU, C.; MORARU, C.I. Microbial retention and membrane fouling during low temperature microfiltration of skim milk using ceramic membranes. In: CONFERENCE OF FOOD ENGINEERING, 9., 2005, [Cincinnati]. [Anais]. Columbus: [s.n.], 2005. p.182-190.

GLIMENIUS, A.R.; JANSSON, G.T.; KEMI, K.W.H.; SANDBLOM, R.M. Filtering method for separating skim milk from milk products. US n.4140806 A, 27 Jan. 1976, 20 Feb. 1979.

GOUDÉDRANCHE, H.; FAUQUANT, J.; MAUBOIS, J.-L. Fractionation of globular milk fat by membrane microfiltration. Le Lait, v.80, p.93-98, 2000. DOI: 10.1051/lait:2000110.

HOFFMANN, W.; KIESNERM C.; CLAWIN-RÄDECKER, I.; MARTIN, D.; EINHOFF, K.; LORENZEN, P.C.; MEISEL, H.; HAMMER, P.; SUHREN, G.; TEUFEL, P. Processing of extended shelf life milk using microfiltration. International Journal of Dairy Technology, v.59, p.229-235, 2006. DOI: 10.1111/j.14710307.2006.00275.x.
HORWITZ, W. (Ed.). Official methods of analysis of AOAC International. $17^{\text {th }}$ ed. Arlington: Association of Official Analytical Chemists, 2000.

LORENZEN, P.C.; CLAWIN-RÄDECKER, I.; EINHOFF, K.; HAMMER, P.; HARTMANN, R.; HOFFMANN, W.; MARTIN, D.; MOLKENTIN, J.; WALTE, H.G.; DEVRESE, M. A survey of the quality of extended shelf life (ESL) milk in relation to HTST and UHT milk. International Journal of Dairy Technology, v.64, p.166-178, 2011. DOI: 10.1111/j.1471-0307.2010.00656.x.

OLESEN, N.; JENSEN, F. Microfiltration: the influence of operation parameters on the process. Milchwissenschaft, v.44, p.476-479, 1989.

RYSSTAD, G.; KOLSTAD, J. Extended shelf life milk - advances in technology. International Journal of Dairy Technology, v.59, p.85-96, 2006. DOI: 10.1111/j.1471-0307.2006.00247.x.

SCHAFFNER, D.W.; MCENTIRE, J.; DUFFY, S.; MONTVILLE, R. Monte Carlo simulation of the shelf life of pasteurized milk as affected by temperature and initial concentration of spoilage organisms. Food Protection Trends, v.23, p.1014-1021, 2003.

SCHMIDT, V.S.J.; KAUFMANN, V.; KULOZIK, U.; SCHERER, S.; WENNING, M. Microbial biodiversity, quality and shelf life of microfiltered and pasteurized extended shelf life (ESL) milk from Germany, Austria and Switzerland. International Journal of Food Microbiology, v.154, p.1-9, 2012. DOI: 10.1016/j. ijfoodmicro.2011.12.002.

SEIXAS, F.N.; FAGNANI, R.; RIOS, E.A.; PEREIRA, J.R.; TAMANINI, R.; BELOTI, V. Comparação de métodos para detecção de fosfatase alcalina e peroxidase em leite. Revista do Instituto de Laticínios Cândido Tostes, v.69, p.17-24, 2014.

SOUZA, V.; NADER FILHO, A.; FERREIRA, L.M.; CERESER, N.D. Características microbiológicas de amostras de leite de tanque comunitário. Arquivo Brasileiro de Medicina Veterinária e Zootecnia, v.61, p.758-761, 2009. DOI: 10.1590/ S0102-09352009000300035.

TAN, T.J.; WANG, D.; MORARU, C.I. A physicochemical investigation of membrane fouling in cold microfiltration of skim milk. Journal of Dairy Science, v.97, p.4759-4771, 2014. DOI: 10.3168/jds.2014-7957.

UNITED STATES PUBLIC HEALTH SERVICE. Grade "A" pasteurized milk ordinance. 2011. Available at: <http://www. fda.gov/downloads/Food/GuidanceRegulation/UCM291757.pdf > . Accessed on: Dec. 192014.

WALSTRA, P. Concentration process. In: WALSTRA, P.; GEURTS, T.J.; NOOMEN, A.; JELLEMA, A.; BOEKEL, M.A.J.S. van. Dairy technology. New York: Marcel Dekker, 1999. p.169-202.

WALSTRA, P. Membrane processes. In: WALSTRA, P.; WOUTERS, J.T.M.; GEURTS, T.J. Dairy science and technology. $2^{\text {nd }}$ ed. Boca Raton: CRC Press, 2005. p.341-356.

Received on June 2, 2015 and accepted on June 8, 2016

Pesq. agropec. bras., Brasília, v.51, n.8, p.990-997, ago. 2016 DOI: 10.1590/S0100-204X2016000800011 